\title{
Architectural and Archaeological Views on Railway Heritage Conservation in Mexico
}

\author{
By Marco Hernández-Escampa* \\ Daniel Barrera-Fernández $z^{\dagger}$
}

\begin{abstract}
Industrial heritage is well acknowledged in several countries. However in the specific case of Mexico, this kind of heritage still faces legal, conceptual and technical difficulties in order to be preserved. Railway heritage as a subset of industrial heritage is strongly linked to historic episodes in the country. In order to explore the potential of railway heritage in Mexico in terms of sociocultural values, a research strategy was applied implying both architectural and archaeological approaches. As a result, the social space of railway heritage starts to be understood in a specific case study located in the state of Morelos, as required by the current international trends in heritage conservation. It is expected that this work represents a contribution to the revalorization of this kind of heritage in Mexico and other countries with similar difficulties.
\end{abstract}

\section{Introduction}

Concepts about the architectural heritage which a given society should preserve have drastically changed through time. This happened in part because the definition of built heritage had been related to the interpretive term of "quality". In a preliminary attempt to clarify this concept, the Athens Charter ${ }^{2}$ considered that the "artistic, historic and scientific" values could determine the quality of monuments. Since that moment, such notions have been discussed, modified and expanded. For example, in the Nairobi Recommendation, ${ }^{3}$ the former concept of the single monument was substituted by a broader sense of historical or traditional sets and stress was put in sociocultural values. This same document also stated that such entities should be analyzed including the physical and human surroundings. In short, the social space of monuments becomes a substantial part of them, creating dual entities beyond materiality. Therefore, since then and increasingly, anthropological, archaeological and

* Professor and Researcher, Autonomous University of Oaxaca "Benito Juárez", Mexico.

$\dagger$ Professor and Researcher, Autonomous University of Oaxaca "Benito Juárez", Mexico.

1. J. Litvak and S. López Varela, "El patrimonio arqueológico en México," in $E l$ Patrimonio Nacional de México II, coordinated by E. Florescano. Mexico: Biblioteca Mexicana, Consejo Nacional para la Cultura y las Artes, Fondo de Cultura Económica, 1997.

2. Athens Charter, "The Athens Charter for the restoration of historic monuments," issued in the 1st International Congress of Architects and Technicians of Historic Monuments, Athens, October, 1931.

3. United Nations Educational, Scientific and Cultural Organization (UNESCO), "Recommendation concerning the safeguarding and contemporary role of historic areas," in The General Conference of the United Nations Educational, Scientific and Cultural Organization, nineteenth session, Nairobi, October 26 - November 30, 1976. 
territorial dimensions have been included in the study, conservation and management of built heritage.

In this context of extension of the limits of what is deemed to have heritage value, industrial sites started to be acknowledged firstly focusing on their material values and finally also including their intangible dimension. The Nizhny Tagil Charter, ${ }^{4}$ defined industrial heritage as "the remains of industrial culture which are of historical, technological, social, architectural or scientific value. These remains consist of buildings and machinery, workshops, mills and factories, mines and sites for processing and refining, warehouses and stores, places where energy is generated, transmitted and used, transport and all its infrastructure, as well as places used for social activities related to industry such as housing, religious worship or education". This early definition was later modified to include the intangible dimension linked to industrial buildings. The new approach was expressed in the "Dublin Principles", 5 which considered skills, memories and social life of workers as values related to industrial heritage sites.

In the case of Mexico, collaboration between Architecture and Archaeology has been difficult due to legal reasons expressed in the "Ley Federal sobre Monumentos y Zonas Arqueológicos, Artísticos e Históricos" (Federal Law about Archaeological, Artistic and Historic Monuments and Sites), ${ }^{6}$ valid since 1972 in the country. This legislation determines that the "Instituto Nacional de Antropología e Historia" (National Institute of Anthropology and History) becomes the entity upon which heritage conservation mainly relies. In article 28 , it can be read that archaeological heritage is defined as material culture created prior to Spanish Colonization. As a consequence, archaeological actions and research have concentrated in PreHispanic contexts, leaving aside more recent heritage categories. Following the legal discourse, in Mexico, heritage dated between the $16^{\text {th }}$ and $19^{\text {th }}$ centuries is labeled as "historical" while the material culture created since the $20^{\text {th }}$ century has no immediate legal protection, unless explicit declared of "artistic" value through the "Instituto Nacional de Bellas Artes" (National Fine Arts Institute). Even more, the law establishes hierarchy between the different categories of heritage established. This way, archaeological heritage (Pre-Hispanic) is considered more valuable than the historical one, which in turn has priority over artistic works.

According to the previously exposed arguments, it is possible to state the paradox that recent heritage, mainly that corresponding to the $19-21^{\text {th }}$ centuries,

4. The International Committee for the Conservation of the Industrial Heritage (TICCIH) and United Nations Educational, Scientific and Cultural Organization (UNESCO), "The Nizhny Tagil Charter for the industrial heritage," in The 2003 TICCIH Congress in Russia, Nizhny Tagil, 2003.

5. The International Committee for the Conservation of the Industrial Heritage (TICCIH) and International Council on Monuments and Sites (ICOMOS), "Principles for the conservation of industrial heritage sites, structures, areas and landscapes (The Dublin Principles), " in The 17th ICOMOS General Assembly, Paris, November 28, 2011.

6. Diario Oficial de la Federación 06/05/1972, Ley Federal sobre Monumentos y Zonas Arqueológicos, Artísticos e Históricos. 
is not only unattended but also at risk in Mexico due to the laws established precisely for heritage preservation. Another consequence of the law is the conceptual segregation between archaeological and historical periods, making it harder to accomplish interdisciplinary research as required since decades in the charters and recommendations. This situation becomes critical because unprotected heritage relates directly with the recent historical processes which lead to the contemporary world construction.

In contrast, it is possible to mention that since the mid- $20^{\text {th }}$ century and starting in England, industrial archaeology has faced the study and conservation of recent heritage. Since then, abundant research has been produced not only preserving material culture, but also creating social explanations about the changes in society in recent historical periods. ${ }^{7}$ In contrast, Mexico has a very recent history in protecting industrial sites. The national branch of TICCIH was founded in 2006 and, according to its last report $^{8}$ one of the major challenges of the country is the lack of legislation considering industrial heritage protection. As a result, demolition of redundant industrial sites is a common problem throughout the country. Nevertheless, there is some progress worth to be mentioned. Some federal states, such as Chihuahua and Puebla, have started to develop their own catalogues for protecting industrial sites. The Historical Archive and the Museum of Mining and the Mexican Railway Museum have done the same with the mining heritage in the Pachuca district and Mexican railway buildings, respectively.

In this work, the relevance of railway heritage in Mexico was studied in an interdisciplinary scheme including architectural, historic and archaeological points of view. Such an approach results coherent with the modern trends in heritage conservation. The research is also intended to provide academic options to go beyond the legal definitions of heritage in the country, thus contributing to the study and conservation of recent built heritage in general. In order to do this, aspects about industrial archaeology rise and scope were explored. Particularly, stress was put in the social and historical meaning of railway heritage in the Mexican state of Morelos because in such context this kind of heritage was linked with nationwide relevant episodes. Finally a specific case study, named the railway heritage of Barranca Honda, in Morelos, was studied in order to identify architectural properties and sociocultural dynamics related to this kind of heritage.

\section{Industrial Revolution and Heritage in Mexico}

In general, it is accepted that social and economic factors produced profound changes in Europe during the $18^{\text {th }}$ century, leading to the rise of the

7. K. Hudson, Industrial Archaeology (London: University Paperbacks, 1965).

8. B. Oviedo Gámez and I. Hernández Ibar. Reporte Nacional México 2012-2015. Report prepared for TICCIH Mexico, 2016. 
Industrial Revolution in the United Kingdom. ${ }^{9}$ Later the effects of industrialization expanded worldwide at different rates. In the case of Mexico, it has been proposed that the first period of industrialization can be established between 1890 and $1940,{ }^{10}$ which implies that this phenomenon reached the country at a relatively late date.

Pre-capitalist colonial industries existed in Mexico, for example the sugar industry in the states of Veracruz ${ }^{11}$ and Morelos ${ }^{12}$ or the mining industries in sites such as Taxco, Zacatecas and Guanajuato. ${ }^{13}$ Even so, industrial heritage tends to imply the material culture associated with new social structures and above all with new energy sources. ${ }^{14}$ Therefore, industrial heritage relates directly to the economic, historical, technological and cultural changes which affected societies in order to produce the contemporary scene. This argument alone becomes more than enough reason to assess the major relevance of this kind of heritage, beyond any aesthetical issue. Concrete examples of industrial heritage might include factories, railways, ports, airports, gas stations, cinemas, mining installations and anything else related to these, including housing in the industrial sites ${ }^{15}$ (Figure 1).

At this point, it can be discussed that some categories of industrial heritage might not be considered strictly architectural in nature. Instead, they might be the direct product of Engineering. Still, the technological advances produced by both disciplines during the historical period under analysis provided new constructive and aesthetical proposals to building in general. Even more, the anthropological or archaeological approach tends to dissipate such social constructed difference. Instead, built heritage is conceived as material culture in a more general sense.

9. E. Hobsbawm, En torno a los orígenes de la Revolución Industrial, 26 ed. Mexico: Siglo Veintiuno Editores, 1988; R. C. Allen, The British industrial revolution in global perspective (Cambridge: Cambridge University Press, 2009).

10. S. Haber, Industria y Subdesarrollo (Mexico: Alianza Editorial, 1992); R. Gallo, Mexican modernity: The avant-garde and the technological revolution (Cambdridge: MIT Press, 2005).

11. G. Cardoso, Negro slavery in the sugar plantations of Veracruz and Pernambuco, 1550-1680: a comparative study (University Press of America, 1983).

12. C. E. Martin, Rural society in colonial Morelos (University of New Mexico Press, 1985).

13. P. J. Bakewell, Silver mining and society in colonial Mexico, Zacatecas 1546-1700, no. 15 (Cambridge: Cambridge University Press, 1971); J. Castrejón Diez, Una ciudad minera en sus orígenes (Artes de México, 1989); J. L. C. Ortigosa, "Mineras en el Guanajuato colonial," Temas americanistas 18 (2005): 4-39.

14. Hobsbawm, En torno a los orígenes de la Revolución Industrial.

15. M. Stratton and B. Trinder, Twentieth Century Industrial Archaeology (London: Spon Press, 2000); P. Neaverson and M. Palmer, Industrial archaeology: principles and practice (Routledge, 2012). 


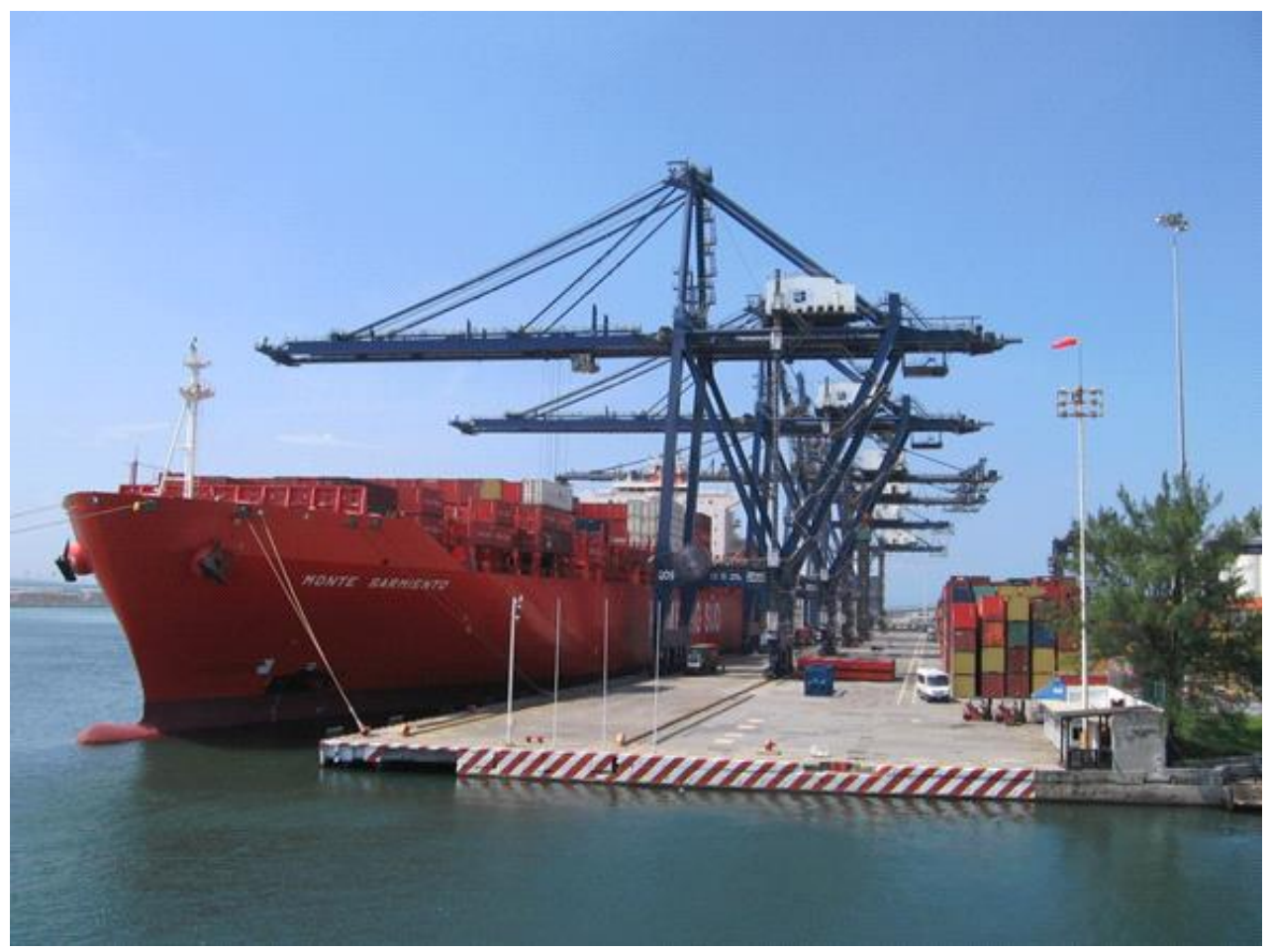

Figure 1. Port Facilities in Veracruz, Mexico

Source: Authors.

\section{Historical Aspects of Railway Heritage and its Role in Territorial Organization}

The gradual appearance of the railway in the territories determined the economic, social and geographic use and meaning of the landscape and time during the $19^{\text {th }}$ century. ${ }^{16}$ The use of rails to guide vehicles can be traced back far away in time to Egyptian and Roman antiquity. Despite, these remote precedents, the first essay to propel a wagon recurring to a steam powered machine dates from around 1770. This first trial is attributed to the French engineer Joseph Cugnot. However, the first railway as such is considered the one created between Liverpool and Manchester, opened on September $15^{\text {th }}$, $1830 .{ }^{17}$

After the Independence War, in the early $19^{\text {th }}$ century, territorial and demographic knowledge was poor in Mexico. ${ }^{18}$ Deteroriation of roads and the consequent lack of communication in such a vast territory were two of the

16. W. Schivelbusch, The railway journey: The industrialization of time and space in the nineteenth century (University of California Press, 2014).

17. R. E. Carlson, The Liverpool \& Manchester Railway Project, 1821-1831 (David \& Charles, 1969); G. D’Estrabau, Historia de las Comunicaciones y Transportes en México El Ferrocarril (Mexico: Secretaría de Comunicaciones y Transportes, 1988).

18. S. Ortiz Hernán, Los ferrocarriles de México. Una visión social y económica, first edition in two volumes. Vol. I: La luz de la locomotora. Mexico: Ferrocarriles Nacionales de México, 1987. 
factors implied in such a situation. Around 1823, official documents only considered three functional main roads still under operation: Mexico CityVeracruz, Mexico City-Acapulco and "Tierra Adentro" (an inland road to the northern territories). ${ }^{19}$ Road inefficiency prevailed until the $1870 \mathrm{~s}$. In fact, during those decades, the use of wheel based transports diminished in favor of animal traction, which became the dominant transport system in the country. Such process has been considered as opposite to technological advance and therefore involution in nature, ${ }^{20}$ especially if compared with the previous functional colonial road system which allowed commerce and communications in general during the precedent centuries.

According to early sources, the first project to introduce the railway in Mexico appeared in 1837 and took into account a considerable amount of foreign investment. ${ }^{21}$ However, the first built railway would delay a number of decades to exist. Between 1850 and 1876, the Mexican government granted about fifty concessions and $93 \%$ of them did not yield any result. The only line built in that period was the railway between the Atlantic port of Veracruz and Mexico City, finished in $1873 .^{22}$ It can be mentioned that besides the social difficulties, topography played a major role in such a delay. The Mexican plateau rises around 2,200 meters above the sea level and mountain chains rise near the coast. Therefore, the technical challenge, given the smooth slope required for the railway, was huge.

Even when the economic progress supposedly associated to the building of the railway could benefit to both, liberal and conservative parties of the epoch, the fact that foreign investment was included in the projects caused severe criticism in the media. An example of such attitude can be seen in a political cartoon published in the "Pluma Roja" (Red Pen) magazine on November $19^{\text {th }}$, 1867 (Figure 2) where the Mexican nation is represented by a woman swept along by a train. ${ }^{23}$

19. D’Estrabau, En torno a los orígenes de la Revolución Industrial.

20. P. Riguzzi, Ferrocarriles y vida económica en México, 1850-1950: del surgimiento tardío al decaimiento precoz (Toluca: El Colegio Mexiquense, 1996).

21. F. W. Powell, The railroads of Mexico (Stratford, 1921).

22. Riguzzi, Ferrocarriles y vida económica en México, 1850-1950: del surgimiento tardío al decaimiento precoz.

23. E. Acevedo, La caricatura política en México en el siglo XIX (Mexico: Círculo de Arte Consejo Nacional para la Cultura y las Artes, 2000). 


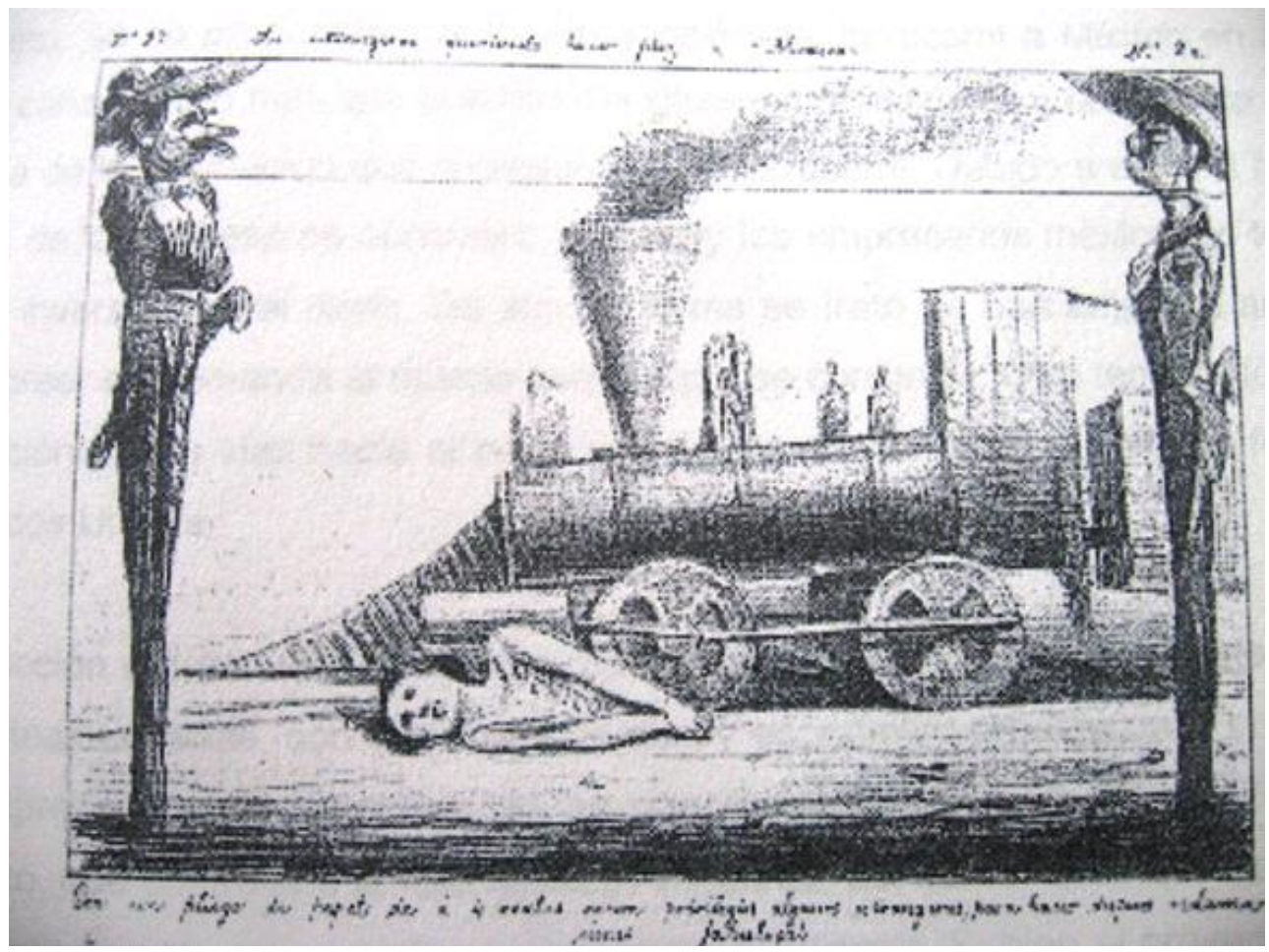

Figure 2. Political Cartoon Questioning Foreign Investment in the Railway Construction in Mexico during the $19^{\text {th }}$ Century

Source: Acevedo, 2000.

Deterioration of roads and the massive use of animal based transport also produced social resistance. In this case, reluctance to accept the railway introduction came from the owners of the beasts. This response was especially strong in the cases of the states of Puebla and Veracruz, where the first Mexican railway was actually built. ${ }^{24}$ Another phenomenon related to the railway construction was the appearance of new agricultural products. Coffee plantations covered great extensions from "Cofre de Perote" mountain downright to the coastal plains of Veracruz. In the highlands of Apan, the agave plant (Agavaceae botanic family, liquor producer) became a massive crop. These changes in economic geography and use and meaning of landscape were done anticipating the transport potential of the new technology. ${ }^{25}$

It has been stated that the railway introduction in Mexico was related more to politics than to actual economic changes. According to that posture, the technological and economic situation of the country did not urgently require such major innovation. This was the reason why the economic benefits for the enterprises were considered doubtful and Mexican investors showed the tendency to evade relationships with the new transport industry. In some way, the railway was an economic sector which had to create itself and its demand at the same time, quite a great deed from any point of view. Another relevant

24. Riguzzi, Ferrocarriles y vida económica en México, 1850-1950: del surgimiento tardio al decaimiento precoz.

25. D’Estrabau, En torno a los orígenes de la Revolución Industrial. 
discussion in the country was the convenience of building railways to the North and their future incorporation to the system already present in the United States. This topic related to the previous territorial loss by which that country acquired more than half of the former Mexican territory. A new invasion was felt imminent. ${ }^{26}$

Despite the above explained processes, the interaction between foreign investors, at first British and later also from the United States, with the economic and political developments lead to the creation of railway companies. One of such companies was called "Ferrocarril Interoceánico" (Interoceanic Railway), which held control over the route from Mexico City to Veracruz and also to the state of Morelos. A precedent of this association was called "Ferrocarril Mexicano" (Mexican Railway). As indicated by its name, the original goal of these organizations was to create a railway that would make a bridge to connect the Atlantic and the Pacific oceans. The result was partial because Mexico City and the port of Veracruz got connected. However, the route all the way to the Pacific was completed later by the "Ferrocarril México, Cuernavaca y Pacífico" (Mexico, Cuernavaca, Pacific Railway) company some years later (Figure 3).

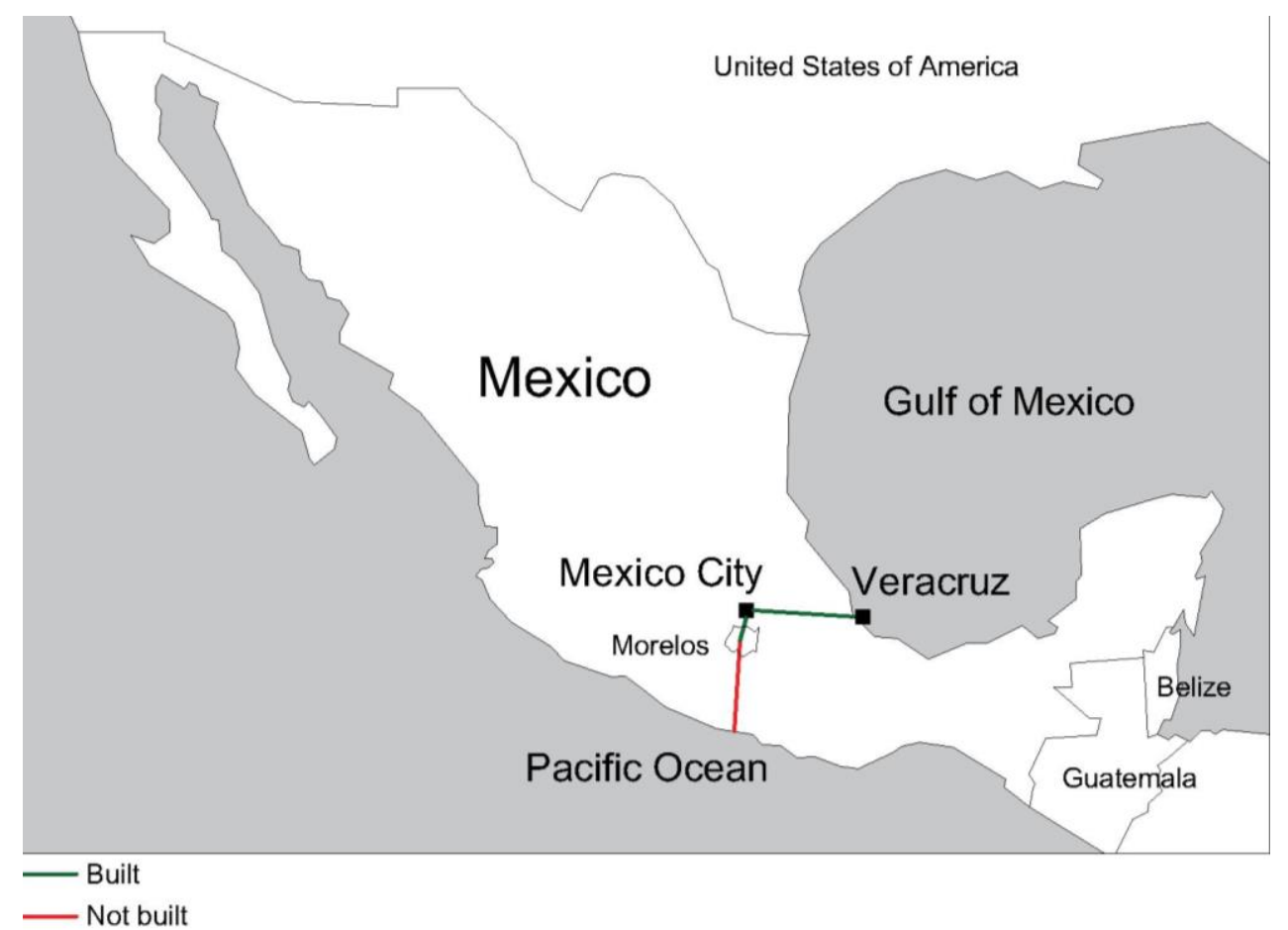

Figure 3. Schematic Route Built and Left Unbuilt by the "Ferrocarril Interoceánico"

Source: Authors.

26. Riguzzi, Ferrocarriles y vida económica en México, 1850-1950: del surgimiento tardío al decaimiento precoz. 
In this sense, a relevant primary source is known as Map of the Interoceanic Railway of Mexico, located at the library of the University of Arizona in Tucson. This map was published in London in the 1890s by the Mexican Southern Railway Company. The document measures 48 x $78 \mathrm{~cm}$, fold to $26 \times 11 \mathrm{~cm}$. Cartography includes the southern United States, Mexico, Guatemala and parts of Honduras and El Salvador. According to this map, by the time of its publication the Mexican railway system consisted of 519 miles of built and functional railway. A detail shows the central portion of Mexico and an altitude profile. On the reverse side, tourist information, schedules, itineraries and other guidelines are explained (Figure 4).

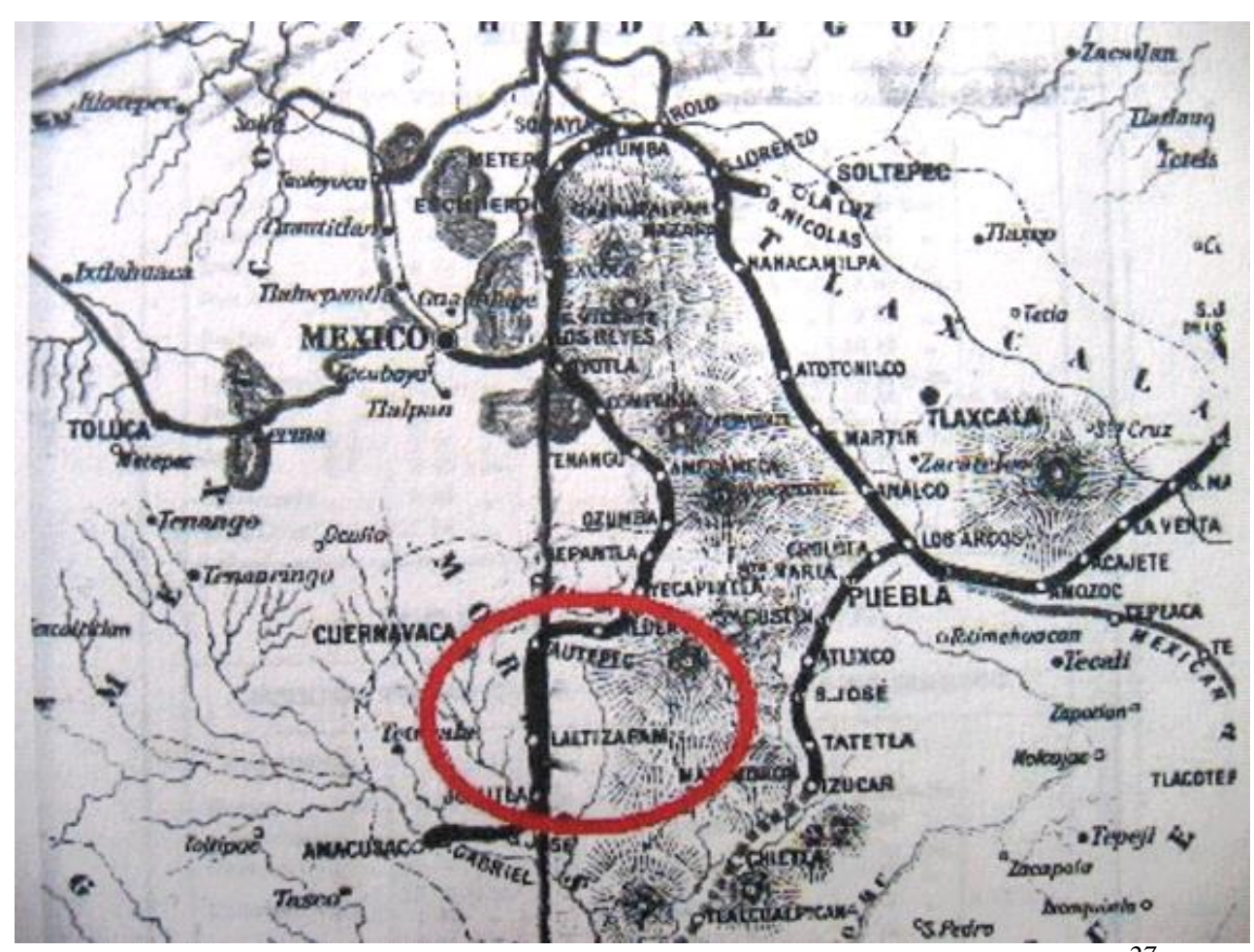

Figure 4. Detail of the Map of the Interoceanic Railway of Mexico. ${ }^{27}$ The Red Circle Added by the Author Highlights the State of Morelos where the Project Ended, not Continuing to the Pacific and where Some Historic Events about the Mexican Revolution Occurred.

Source: Authors, original source: Map of the Interoceanic Railway of Mexico, c1890.

\section{Railways in Morelos State and Some Socio-Territorial Dynamics}

As already explained the Interoceanic Railway project joined Mexico City and Veracruz and later tried, without success, to reach the Pacific Ocean. The advances to accomplish the second phase physically took place in the territory of the State of Morelos, located south of Mexico City. The advances however

27. Map of the Interoceanic Railway of Mexico (The University of Arizona Library. Special Collection. G4411.P3 1890z, M3. c1890). 
created the local railway system of this state. Morelos was established as political entity en 1869 joining territories that previously belonged to the states of Mexico and Puebla. According to historic sources, around 1882 the capital city was Cuernavaca and five settlements were considered in the range of the cities: "Cuernavaca, Cuautla de Amilpas, Yantepec de Zaragoza, Tetecala de la Reforma y Jojutla de Juares". Following that same source, the territory included 13 towns, 106 villages, 7 smaller settlements, 48 haciendas and 54 ranches. Such settlement pattern was the result of complex processes related to the sugar cane industry established in the region since the Contact Period during the 16th century, which in turn was developed over a Prehispanic urban pattern. However, the current system is based on the transformations that happened during the 19th century due to the industrialization process and the railway introduction. Basically, the improved technology and transport system intensified sugar cane production, leading to social and resource pressure because the haciendas deprived towns in the process.

Resource limitations imposed to local towns in favor of the sugar cane industry lead to the rise of the Mexican Revolution, started in 1910 by General Emiliano Zapata in Anenecuilco, against the presidential system of General Porfirio Díaz. The railway heritage would relate to this historic episode, increasing its symbolism and meaning. This way, the argument used to explain the Zapatista rebellion during that epoch relates directly to economic and social aspects materially sustained on the technological cultural change. According to Womack, during 30 years, the great landlords of Morelos, sugar cane industry owners and managers, had disputed and deprived the town of Anenecuilco from rights over their lands and water resources. Around 1909 the pressure exerted by such struggle had become unbearable by the people of that town and many others. Common lands devoted to subsistence agriculture were progressively used to produce sugar cane. Studies in other agricultural contexts show that this kind of historic development produces severe damages to populations in terms of illness, undernourishment and social aspects.

Such historic approaches emphasize the social aspects of the topic. Therefore, it is goal to achieve assessing the relationship between the industrialization rate and the increased demand of raw materials required to maintain the new productive output. This way, and subject to confirmation, it is possible to suggest that the industrialization itself, leaded by the introduction of the railway, might be the basal reason why the social outburst ignited in Mexico during the early 20th century.

Detailed historic analyses of the Mexican Revolution have been done in detail in the scientific literature and such developments are not the main focus of this work. Instead, the sense of this research regards the strategic and symbolic role that the railway, understood as built heritage and therefore relevant to Architecture and Engineering, played during such a historic episode. Specifically, in the Morelos State the control over the railways built prior to 1910 constituted a major military goal, related to territorial strategy. As explained before, two such systems already existed by that time: The Interoceanic and the Pacific railways. 
Just as it happened in the rest of the country, the violent circumstances during the Revolution provoked the notorious destruction of the rails, equipment and associated buildings such as stations and workshops. According to President Madero, between 1911 and 1912, 390 kilometers of new railways were built in the country and projects existed to communicate the states of Chiapas, Tabasco and Oaxaca. The railways Aguascalientes-Tepic and Baja California-Sonora were also planned. Nevertheless, the suggested peace and progress were mere fictions. In a letter sent to the Governor of Morelos, dated April 10th 1912, the President himself asked to dismantle any obstacle and weed 200 meters on each side of the railways in Zapatistas territory. As it can be seen, the control of the railways implied geopolitical advantages to whatever side possessed it.

The first attack of the Zapatistas to the railway system occurred in the Ferrocarril Mexico Cuernavaca y Pacífico. On April 29th, 1911 chief Labastida attacked El Parque Station, near to Cuernavaca, capital city of Morelos. Later, on July 20th, 1912 General Genovevo de la O caused an accident in the location called La Cima near the limits of Morelos and Mexico City. A battle started and 82 persons were killed. The first attack to the Interoceanic Railway occurred on August 12th, 1912 in the Ticuman Canyon. During this violent episode two war reporters and a photographer were killed among others, which caused great indignation to the government.

Later, during Carranza's government orders were to destroy Zapata, his army and supporters. In 1916, slaughters were performed in the town of Tlaltizapán, where Zapata had his base. In one of such massacres 180 residents were killed. In a second one, 132 men, 112 women and 42 minors lost their lives. As a response, the Zapatistas organized two attacks against the Ferrocarril Mexico, Cuernavaca y Pacífico. The first happened on November 7th that same year in the Xoco Station well into Mexico City's territory and 400 people died. The second one is less documented and we only know about its occurrence. Similar episodes kept happening during the next years in all the territory. Just in 1919, between April and June, the newspapers registered 72 attacks and transit blockades in 18 states. As a protective measure, the government built small fortresses and other military installations near the railways under its control .

In the present, inhabitants of Morelos preserve those events in the form of tales and stories that pass from one generation to another. Another more tangible cultural manifestation can be seen in Anenecuilco, where a small museum was built to preserve the remains of General Emiliano Zapata's birthplace, a small vernacular house. Within this complex there is a mural depicting diverse episodes of the Mexican Revolution and Zapata's deeds. One of the scenes shows locomotive 739 controlled by the Zapatista army. This pictorial representation is based on a photograph of the epoch, nowadays of public domain and which can be bought as a souvenir in the museum and in different popular markets. In some way, all that has been explained to this point shows the indissoluble relationship between the railway and the Mexican Revolution (Figures 5 and 6). 


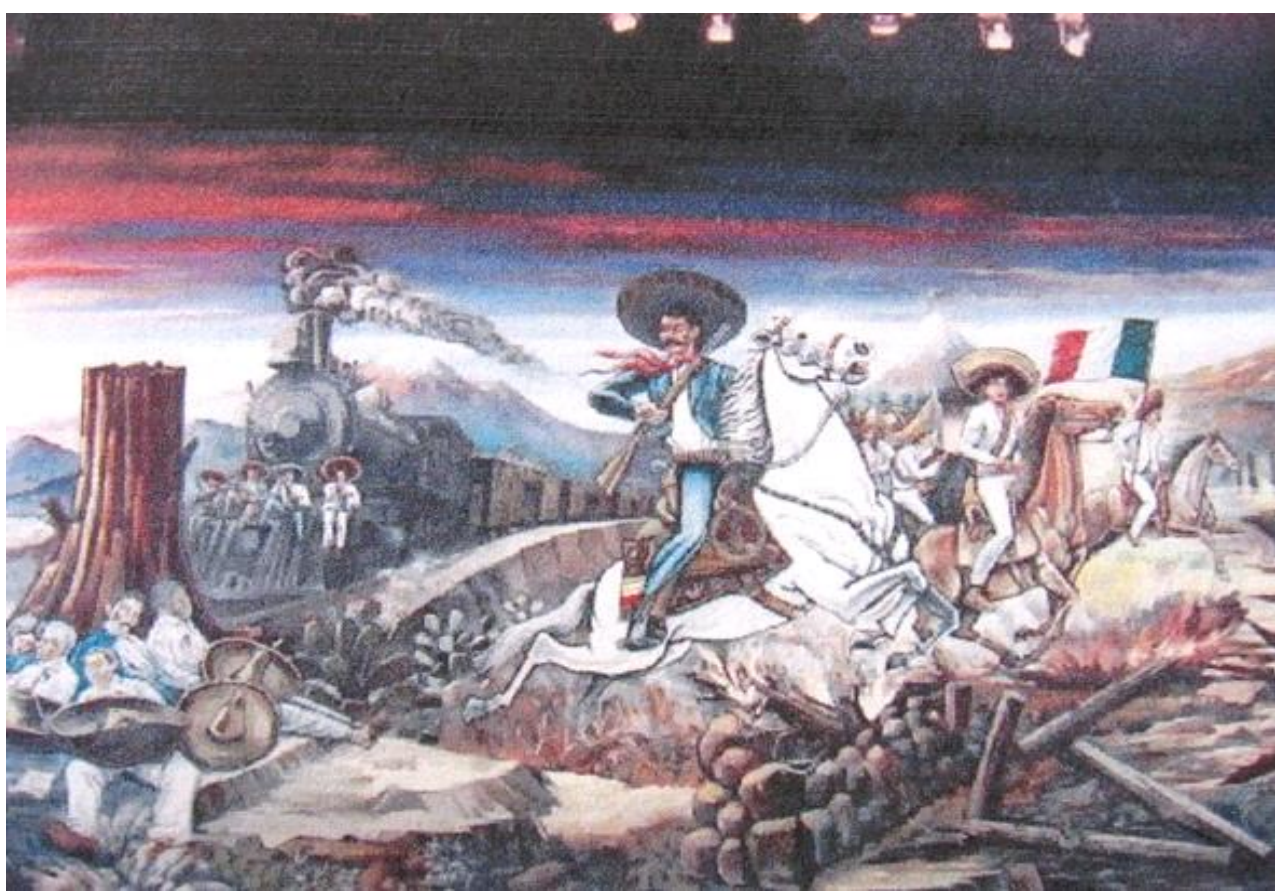

Figure 5. Mural in Anenecuilco Museum

Source: Authors. Photo taken at Anenecuilco Museum.

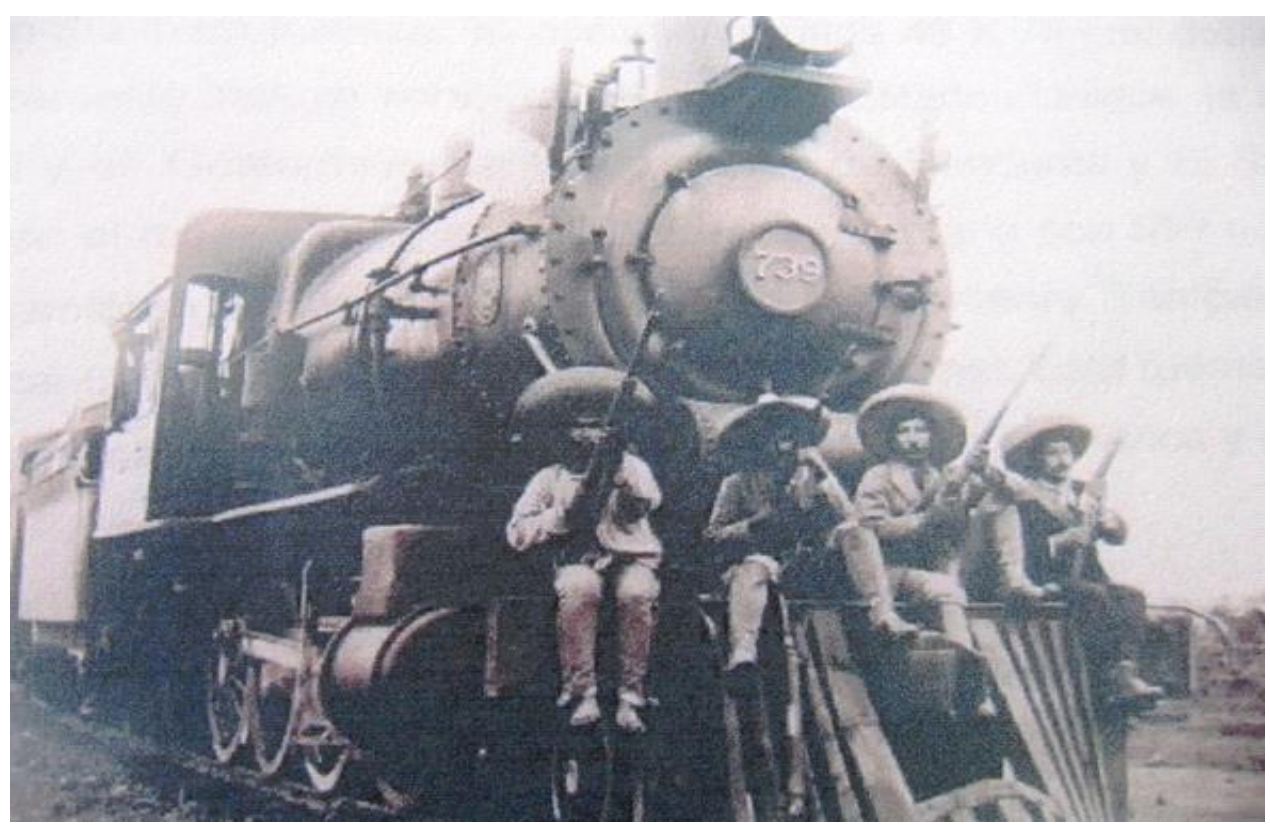

Figure 6. Historic Photo of the Locomotive 739 and Zapatistas

Source: Public domain.

\section{Bridges in the Interoceanic Railway}

In 1874, Gustavo Baz and E. L. Gallo published their work 'Historia del Ferrocarril Mexicano' (History of the Mexican Railway). This publication was later reproduced as facsimile during the 20th century and enriched with more 
information in the appendixes. One section of this book is a recompilation of landscapes including natural and urban scenes and specifically of railway stations and bridges. The images mainly relate to the Veracruz-Mexico section of the Interoceanic Railway and therefore depict sites in the states of Veracruz and Puebla. Some of them are very well known as is the case of the Metlac Bridge (Figure 7), while other structures are less recognizable. Formally there is a great variety in design, employed materials and constructive systems.

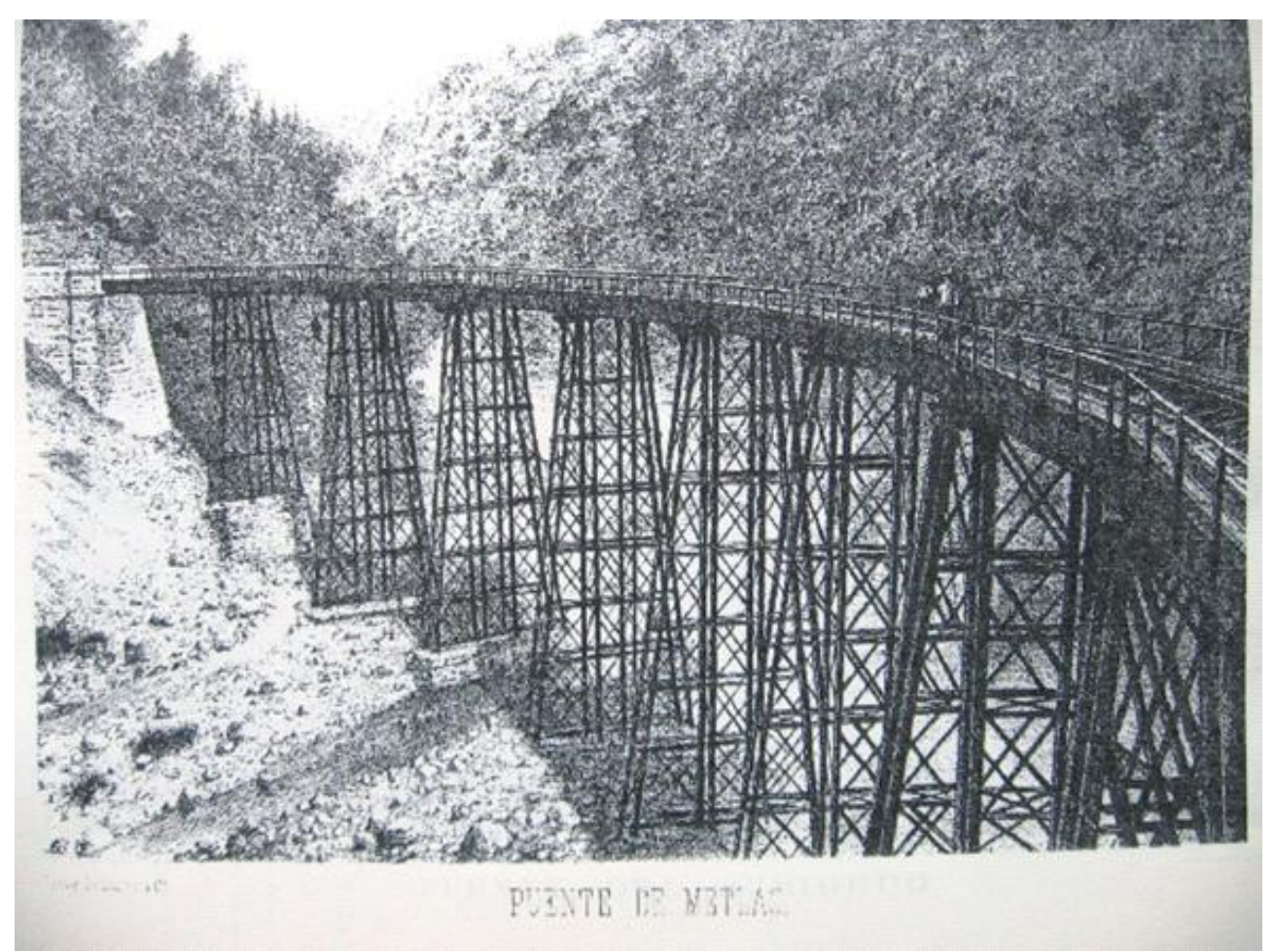

Figure 7. Metlac Bridge

Source: Baz and Gallo, 1975.

For the purposes of this work, focused mainly on the Morelos State, one of the illustrations becomes relevant. That is the case of the Chiquihuite Bridge (Figure 8) which resembles the Barranca Honda Bridge in Morelos. The name of this second bridge can be translated as "deep canyon". Both bridges show a similar design, materials and constructive systems. Two brick pillars sustain armors separated in three sections while two anchors complete the system. In some way, this visual similarity shows the cultural relationship between the whole Interoceanic Railway. In fact, a peculiarity of the industrial heritage contexts in general consists of the great scale of the system. Unlike many preindustrial contexts that are constrained geographically, industrial cases can imply much more extensive distances. In this particular case, the manufacture, diffusion and influence context extends through two continents (Europe and America) and in turn the railway itself expands hundreds of kilometers. 


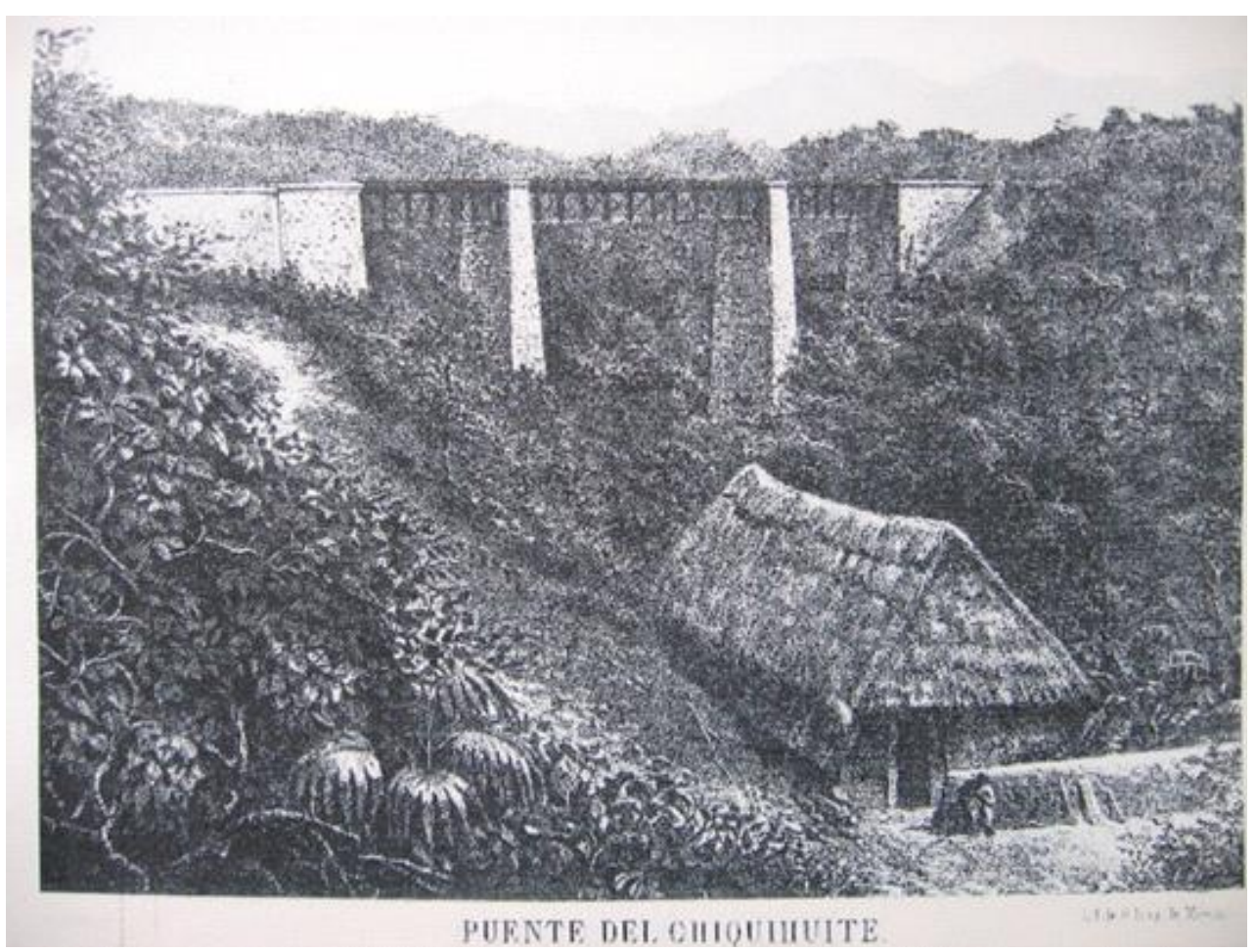

Figure 8. Chiquihuite Bridge

Source: Baz and Gallo, 1975.

The Chiquihuite Bridge crosses the homonymous river. It has got a total length of 68 meters and a maximum height at 33 meters. It is located just to the East of Atoyac and has suffered diverse modifications. Meanwhile, the Barranca Honda Bridge joins a 43 meters long separation between cliffs and its height varies between 8 and 10 meters over irregular terrain, measured in the field.

\section{A Closer Look to Barranca Honda}

As already stated, industrial heritage might imply great scale contexts, such as railways. It is not always possible to study all the geographic extension in detail. Even more, which elements should be preserved and why it implies some technical and conceptual challenges. Therefore, site significance assessment methods are employed from an archeological point of view in order to establish priorities. In the case of the Mexican railways, such assessment has not been performed yet. In this work, a specific subsection of the Interoceanic Railway is further analyzed not only to describe, but also to explore the sociocultural relevance of the site. Originally, the chosen section was located inside the common lands of Barranca Honda, Morelos, fully in revolutionary historic range.

The common lands of Barranca Honda were crossed in a mainly NorthSouth direction by the Interoceanic Railway. The studied area is located between the cities of Yautepec and Tlaltizapán. Prospection was done to find individual built structures associated to the main railway itself. This way, a set 
of seven bridges and two storm drains were identified. Structures were numerated in a North-South direction. Adjacent to Bridge 1 a small fortress was also found. Even when this last structure is strictly out of the common lands, it was included in the study because historic relationships became evident.

Bridge 1, locally simply known as Barranca Honda Bridge is particularly interesting, not only because of its dimensions but also because it shows different building phases. The northern pillar is built with red bricks and carved stones, while the southern one shows a uniform appearance in gray concrete (Figure 9). At the top of this second pillar an inscription can be read, stating the reconstruction of the bridge in 1919 (Figure 10). In the bottom of the canyon, red brick blocks are present, interpreted as the remains of the original southern pillar (Figure 11). Metallic structures crowned the pillars and supported the usual wood-rail system. The context implies that this bridge was attacked during the revolutionary period and built later to re-establish the system.

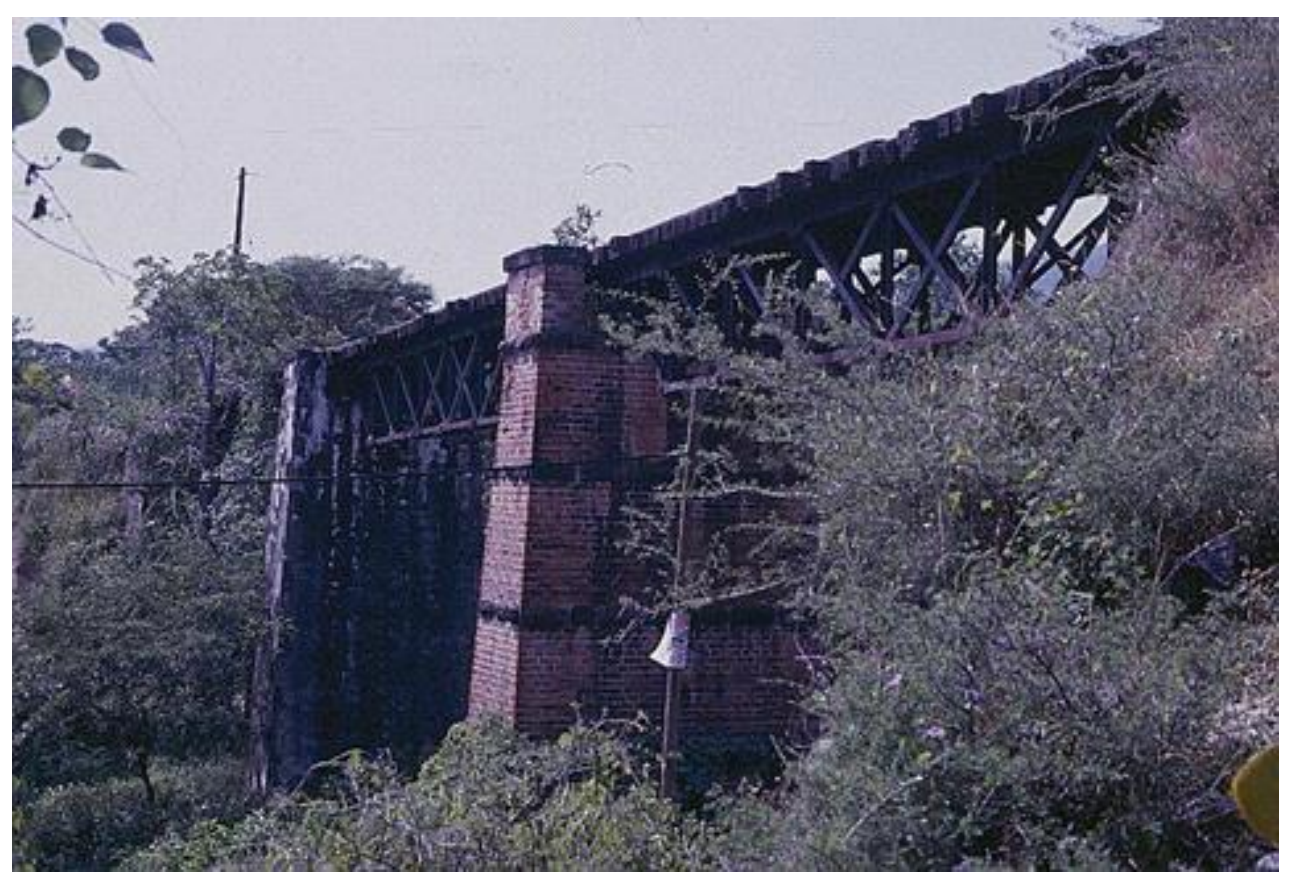

Figure 9. Bridge 1. Contrast between the Brick North Pillar and the South Gray Pillar

Source: Authors. 


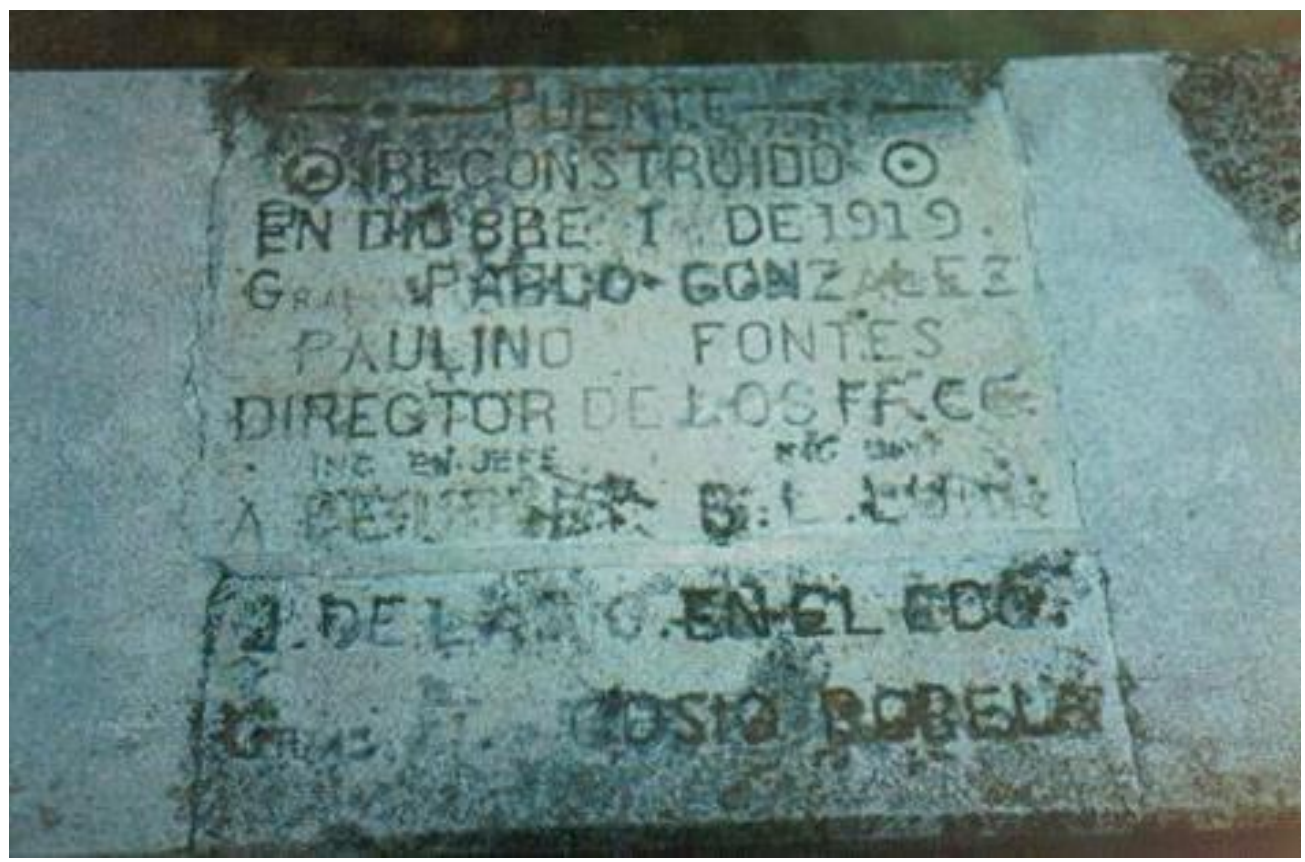

Figure 10. Inscription Stating the Reconstruction of the Bridge in December $1^{\text {st }}, 1919$. Names of Government Officers are also mentioned Source: Authors.

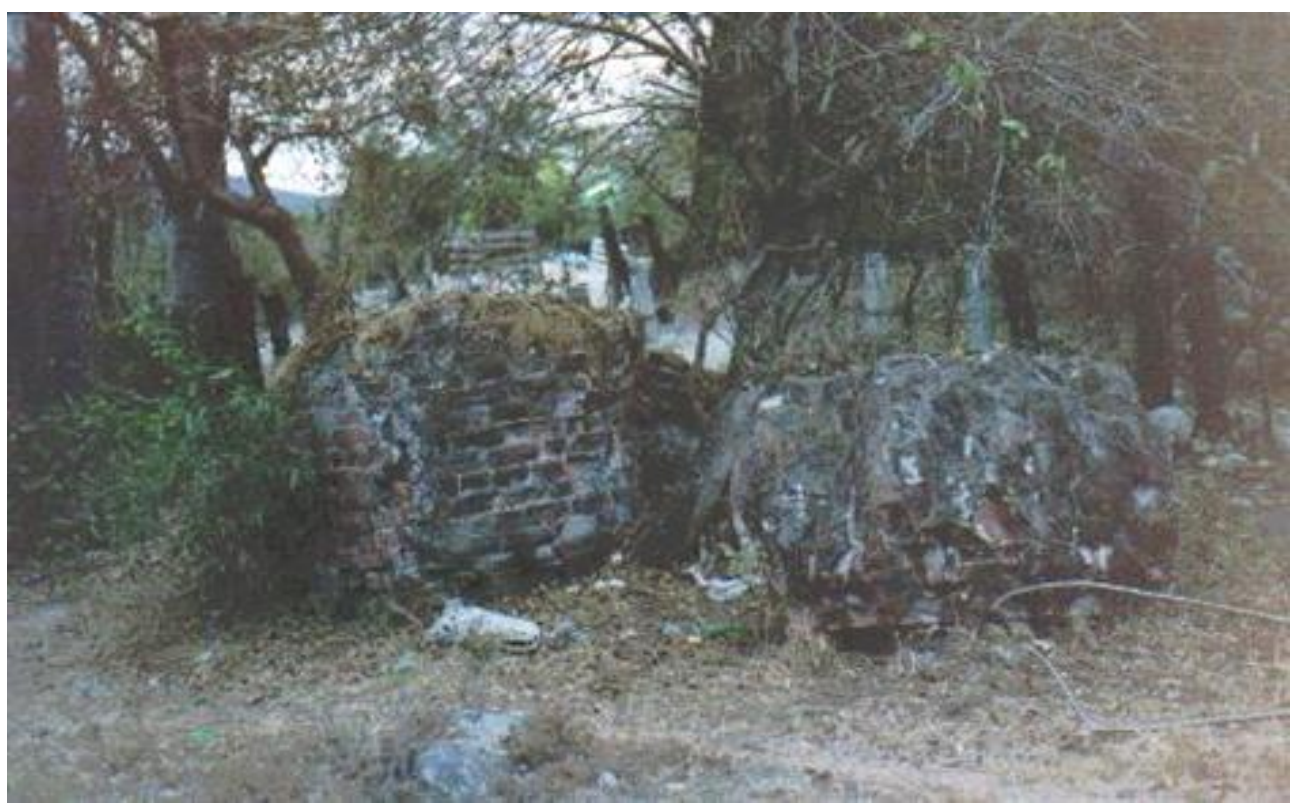

Figure 11. Red Brick Blocks as Rubble in the Bottom of the Canyon, Remains of the Original South Pillar Source: Authors.

The rest of the bridges in Barranca Honda common lands are smaller in scale. They are composed of two bodies or anchors separated by 3-5 m. Most have lost their original upper parts as seen in bridges 2, 3, 4 and 5. Only bridges 6 and 7 still retain metallic girders. The function of these edifications 
was to level lesser depressions of the terrain. These bridges, except bridge 6 were finished with carved stone (Figure 12).

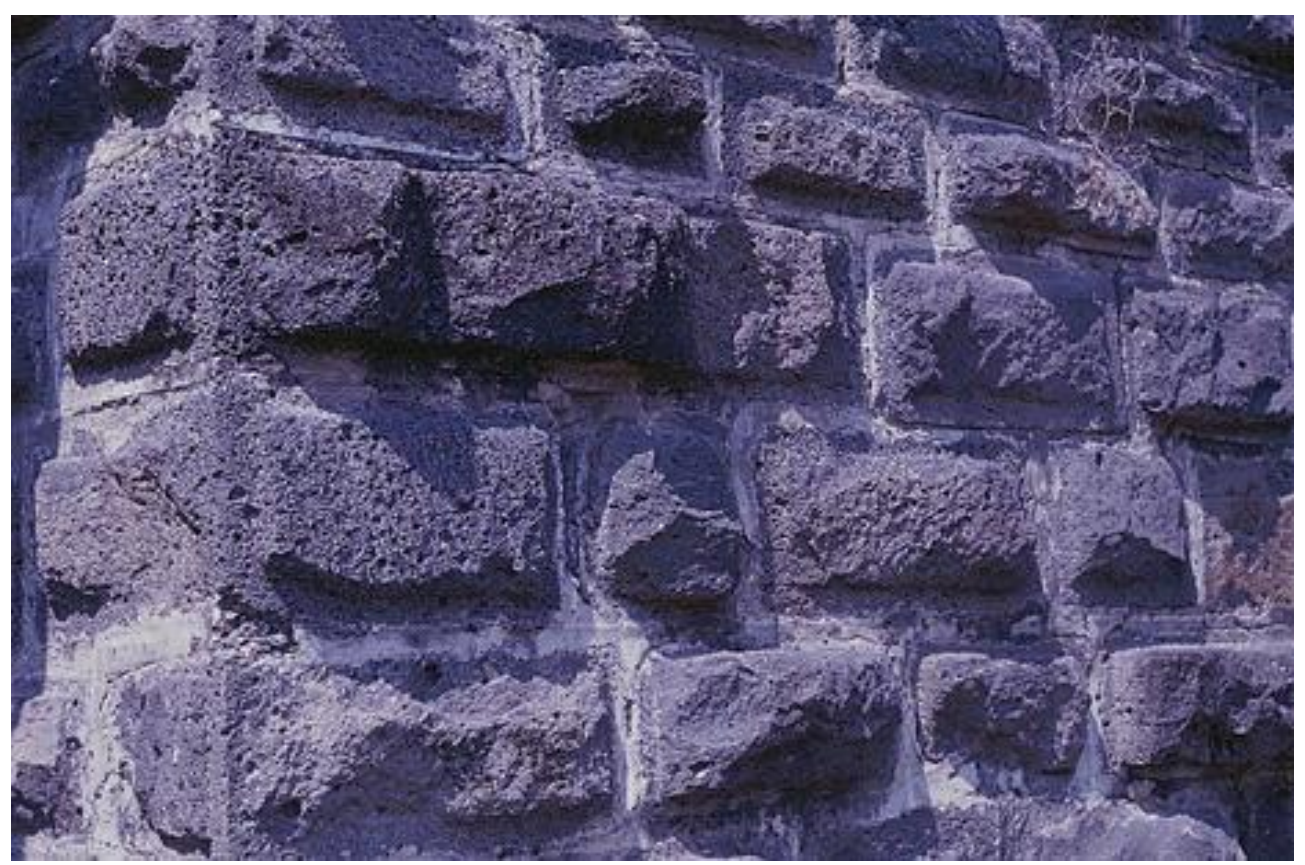

Figure 12. Detail of Carved Stones Present in Bridge 2

Source: Authors

Bridge 6 is locally known as 'Puente Blanco' (White Bridge). The edification is not located in a profound cliff, but it levels a bigger gap of the terrain. Once again a plaque can be seen, this time located in the northern body. The inscription states that the bridge was built in 1945. This date might refer to some kind of restoration, but not to the actual starting point. The southern body is built with red brick just as in Bridge 1, and with carved stones, while the northern body shows a deep layer of brick, just covered with almost white colored cement, hence its local name (Figure 13). Just as Bridge 1, once again, this monument had different phases and might be related to attacks in the past.

a

b
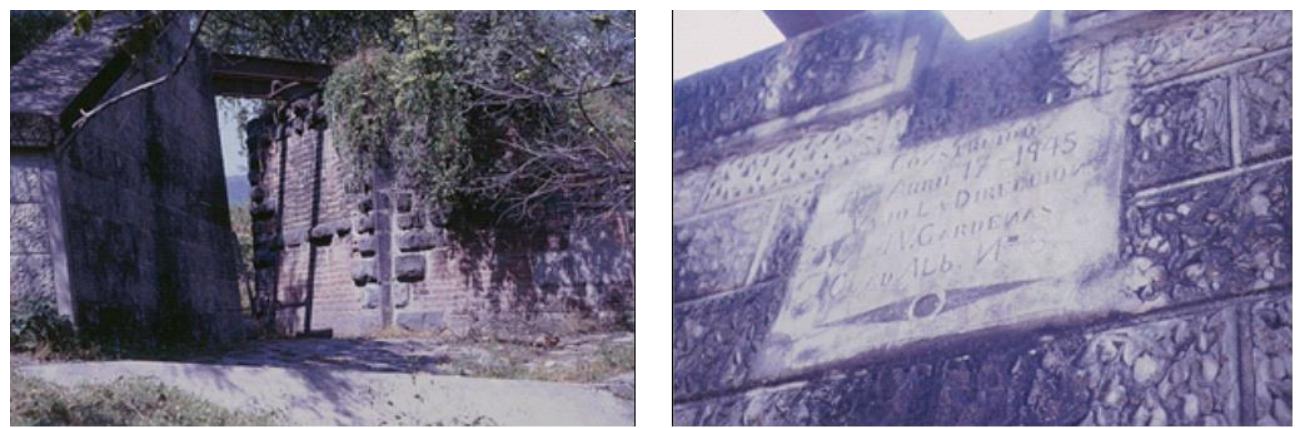

Figure 13. (a) General View of Bridge 6 "Puente Blanco" (b) An Inscription in the Northern Body States that the Bridge was Built on April $17^{\text {th }}, 1945$

Source: Authors. 
Storm drains constitute a fundamental part of railway infrastructure as they allow currents to be conducted, avoiding damage to the system. Two of these elements were identified. The first one is just a small work that conducts excess water from a nearby slope, allowing it to pass under the railway. The second one is much more significant because it conducts the flow of an intermittent stream transversally and under. Storm drain 2 actually is a complex work consistent of a $21.5 \mathrm{~m}$ long and $2.45 \mathrm{~m}$ in height barrel vault. The structure integrity has been maintained, including a sculpted keystone showing the date July $23^{\text {th }}, 1889$ (Figure 14).

a

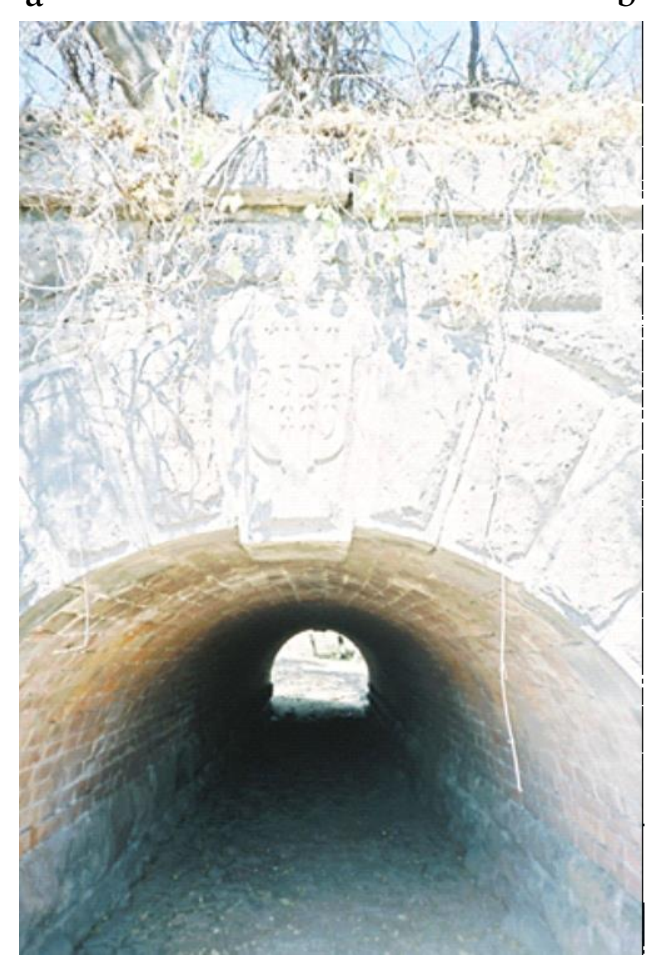

b

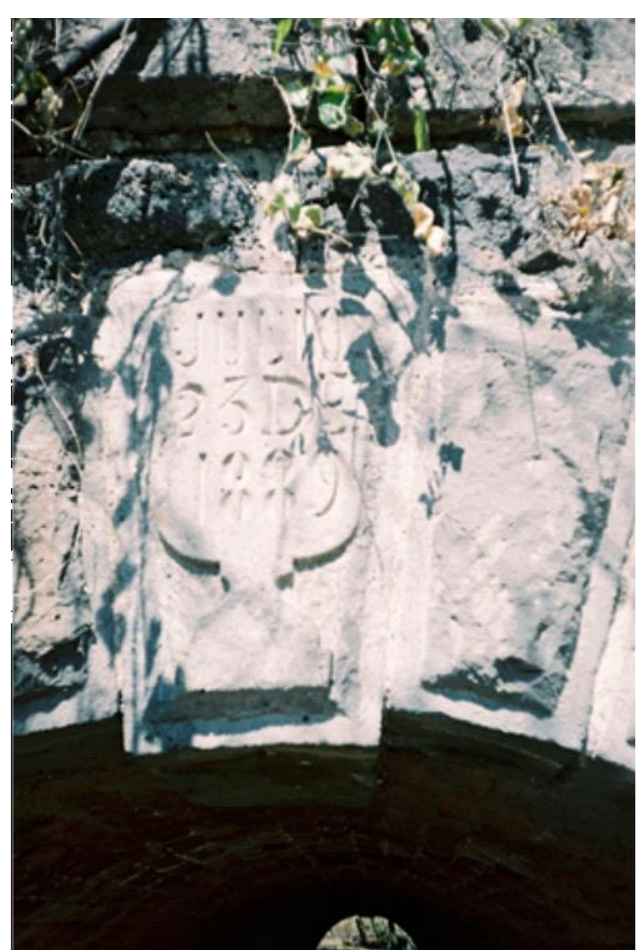

Figure 14. Storm Drain 2. (a) General View. (b) Detail of Keystone Showing 1889 Date

Source: Authors.

Going back to the North, Bridge 1 saves a cliff that separates the Barranca Honda common land from the neighboring El Fortín (small fortress) community in the municipality of Yautepec. This site is named after a small fortress built in the top of a hill, related visually with Bridge 1 (Figure 15). 
a

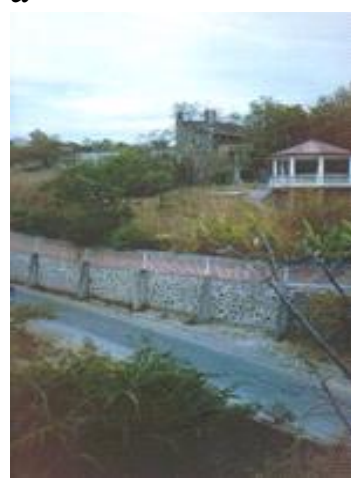

b

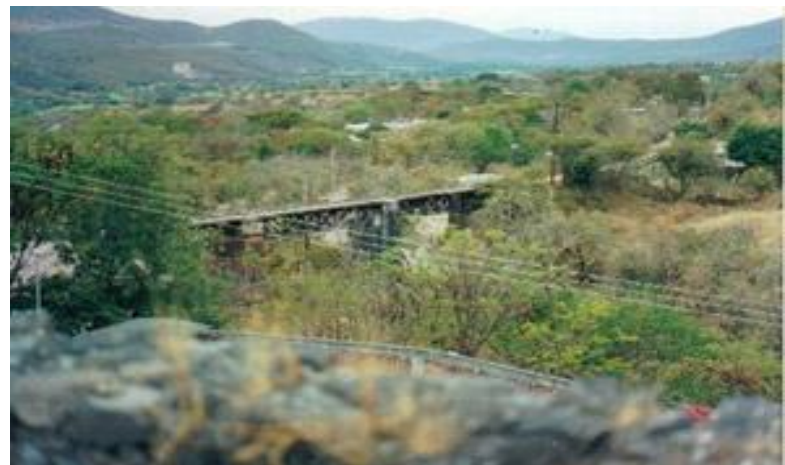

Figure 15. (a) The Small Fortress can be seen from Bridge 1 at the Top of a Hill, Surrounded by Modern Constructions (b) Bridge 1 as seen from the Small Fortress. Visual Relationship Suggests that the Fortress Guarded the Bridge. Source: Authors.

In the present, the fortress is used as a home by an elderly couple. Being a traditional society, this implies that these persons have social prestige as stated by informants. The building itself is rectangular in shape and shows defensive elements in the roof (Figure 16). It is partially built with recycled railway material (Figure 17), presumably from the collapsed pillar from bridge 1 . According to the account of the inhabitants, during the Revolution, the government of President Venustiano Carranza ordered a slaughter to punish Zapata's forces based in Tlatlizapán, just south of the area of study. As an answer, the Zapatistas blew the bridge to avoid further intrusions. Later, the Government repaired the bridge and built a small fortress to protect it. This episode and similar ones indeed occurred as described by historic sources. ${ }^{28}$ Therefore, these industrial remains also relate to local historic memory. Oral tradition coincides with archaeological and architectural analysis. It is also pertinent to mention that this fortress is one of the few examples of military architecture so far described in Morelos, which highlights its importance.

a

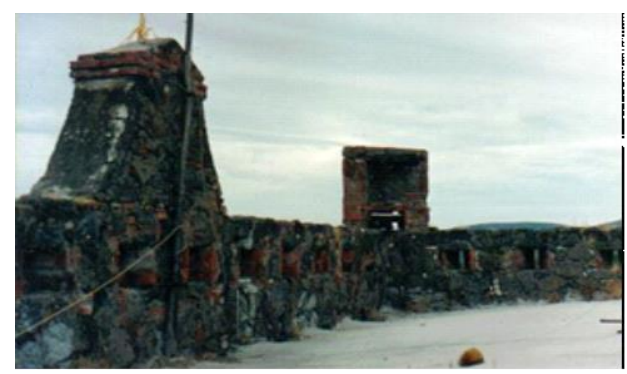

b

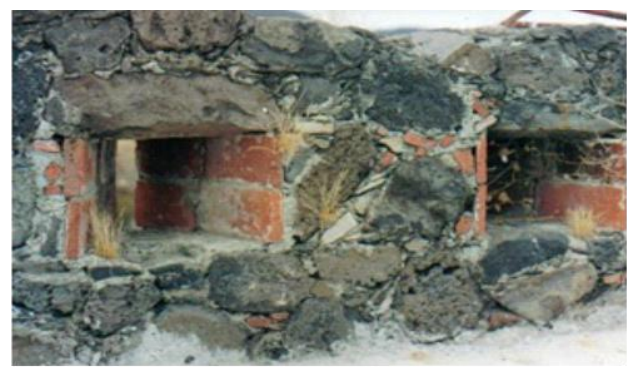

Figure 16. Defensive Structures at the Top of the Small Fortress (a) General View (b) Detail

Source: Authors.

28. Ortiz Hernán, Los ferrocarriles de México. Una visión social y económica; D'Estrabau, Historia de las Comunicaciones y Transportes en México. El Ferrocarril. 


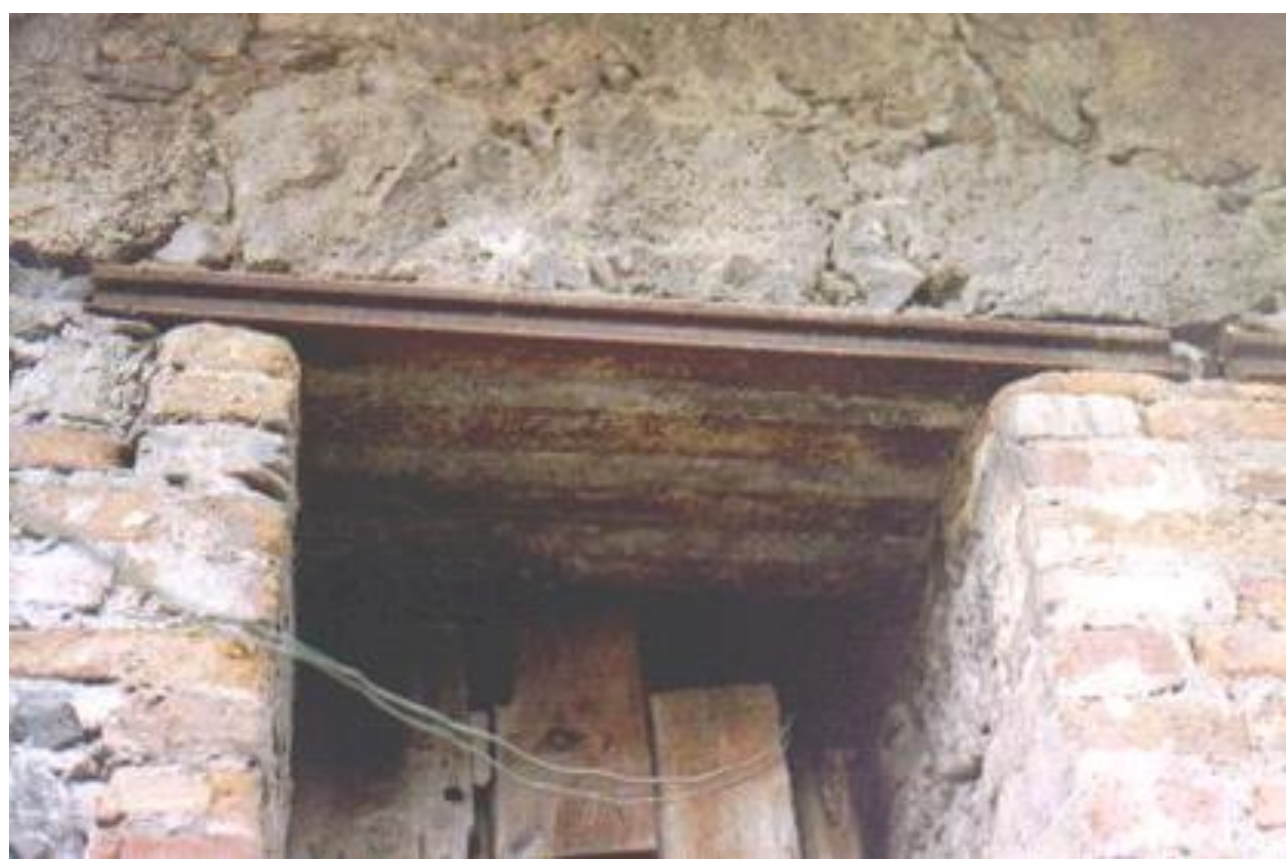

Figure 17. Rails Used to Form a Lintel at the Small Fortress

Source: Authors.

Recycling of railway materials observed in the fortress constitutes an interesting issue. From an ethnoarchaeological point of view, reuse implies resymbolization of material culture, not only a practical solution. ${ }^{29}$ It was observed that people in Barranca Honda constantly extract materials from the abandoned railways to use them in new ways (Figure 18). This might be explained beyond simple practical convenience. In fact, it is important to stress that the materials tend to remain in the town, while people from other communities seem to be much less attached to them. As a contrasting example, in Tres Marías, another community in Morelos, it was recorded that people gather the materials from the railways to sell them away and not for immediate reutilization (Figure 19). The attitude seen in the Barranca Honda area might be related to the events that lead to the edification of the fortress. Possession of railway material could relate to identity or social prestige. Further studies are needed to evaluate this possibility. At the same time, conservation measures should be established since materials extraction implies monument destruction, despite the ethnoarchaeological interpretation.

29. N. David and C. Kramer, Ethnoarchaeology in action (Cambridge: Cambridge University Press, 2001). 

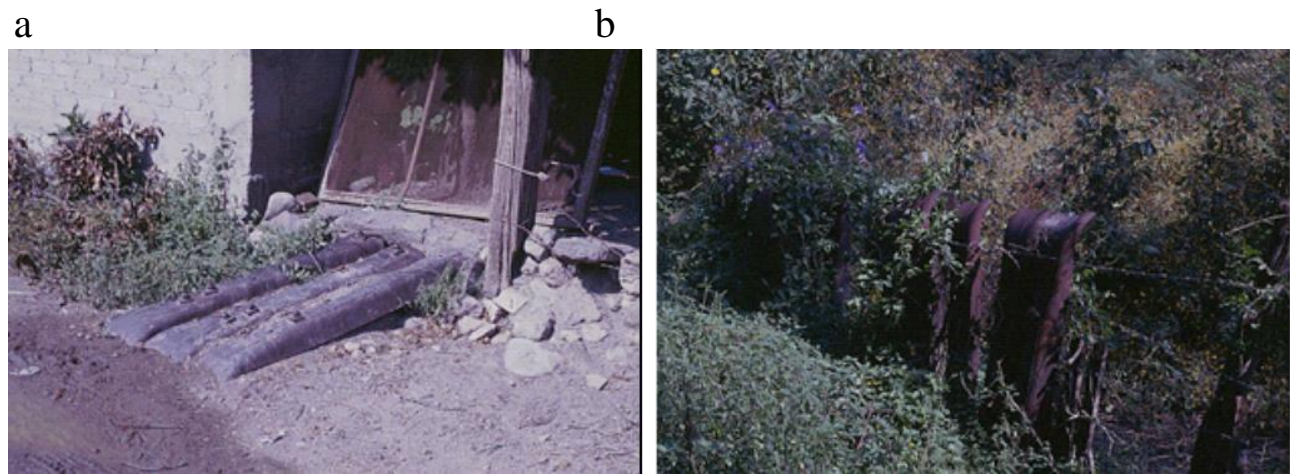

Figure 18. Recycled Railway Materials Used in the Town. (a) Ramp (b) Fence Source: Authors.

Figure 19. (a) Old Railway Station in Tres Marías, Morelos (b) In this Locality the Railway Material is Collected and Sold

a

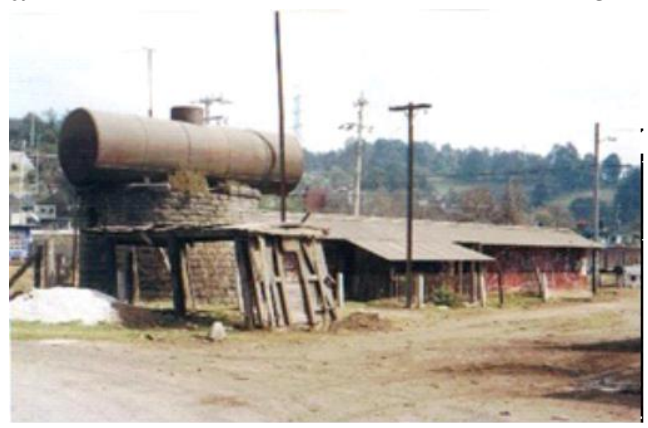

$\mathrm{b}$

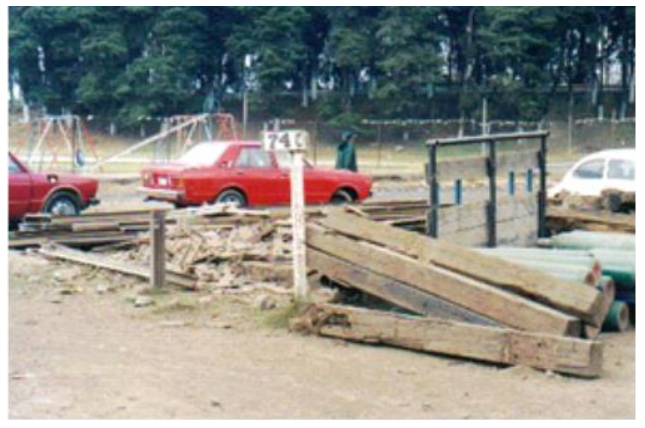

Source: Authors.

Another recycling phenomenon observed implied the railway and the bridges themselves. Once the rails and other elements were retired, the path has become the route to walk from the town to the working fields. In fact, in some bridges, modern concrete plaques now fill the gaps to permit free transit of persons and even small vehicles (Figure 20).

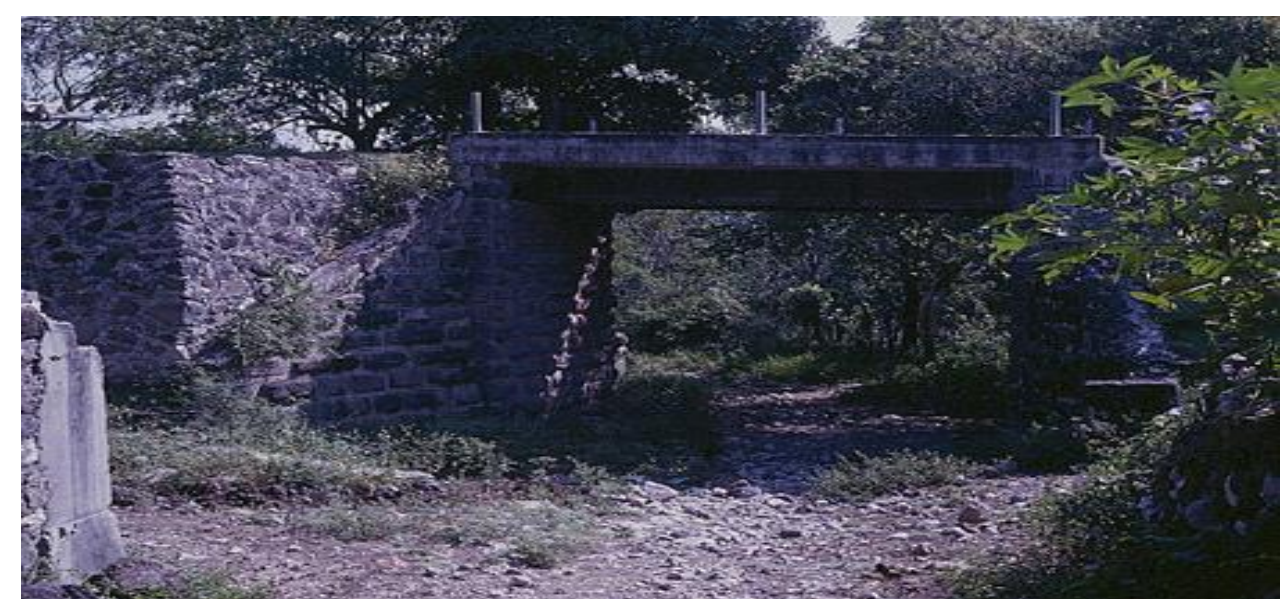

Figure 20. Bridge 4 with Modern Constructive Additions

Source: Authors. 


\section{Conclusions}

Industrial heritage comprises a set of monuments and contexts which have been overlooked in Mexico until recent times. However, in other countries its values have been identified and acknowledged because this heritage category relates with the processes that created the contemporary geographic and sociocultural scene. Therefore, even when some advances do exist, strategies are needed in Mexico in order to study and preserve industrial heritage in general despite and beyond the current legal status. Citizenship participation might be a way to go in order to better assess and work with this cultural heritage.

Railway heritage, conceived as a subset of industrial heritage, appeared in Mexico during the $19^{\text {th }}$ century. It transformed the geographic landscape conception and use in huge territorial extensions. New products were cultivated and even new towns and urban systems were built based in this new technology. During relevant historic moments, the military control over the railway system constituted a major goal both for the Government and the rebels. This way the railway became part of the social imaginary realm despite the fact that in the present, the railway system is basically abandoned in the country. This kind of heritage is especially linked to the historical memory and identity of inhabitants in some localities, to the degree that they use and recycle the materials beyond mere practical reasons.

In this context, the railway track at Barranca Honda and its bridges represent an interesting case study due to the interaction of a neglected heritage asset with new uses brought by residents. Especially the research developed in Bridge 1 resulted in an increased knowledge of these facts from an ethnoarchaeological point of view. Nevertheless, it must be taken into account that reutilization of industrial heritage implies a loss that should be faced reinforcing regulations towards their acknowledgement.

Architectural and archaeological studies are required to further assess the site significance of the vast industrial contexts. It is expected that this work could represent a start in such a direction. The studied railway section yielded a coherent set of individual monuments subject to evaluation as soon as other contexts are studied and comparative studies performed.

\section{Acknowledgements}

The authors want to thank the Centro Regional INAH Morelos for their support in this research.

\section{Bibliography}

Acevedo, E. La caricatura política en México en el siglo XIX [The political caricature in Mexico in the $19^{\text {th }}$ century.] Mexico: Círculo de Arte Consejo Nacional para la Cultura y las Artes, 2000. 
Allen, R. C. The British industrial revolution in global perspective. Cambridge: Cambridge University Press, 2009.

Athens Charter. "The Athens Charter for the restoration of historic monuments." Issued in the $1^{\text {st }}$ International Congress of Architects and Technicians of Historic Monuments. Athens, October, 1931.

Bakewell, P. J. Silver mining and society in colonial Mexico, Zacatecas 1546-1700 (No. 15). Cambridge: Cambridge University Press, 1971.

Baz, G., and E. L. Gallo. Historia del Ferrocarril Mexicano: Riqueza de México en la zona del Golfo á la Mesa Central, bajo su aspecto geológico, agrícola, manufacturero y comercial [History of the Mexican railway: Mexican richness from the Gulf area to the Central Plateau, from its geological, agricultural, manufacturing and commercial aspects.] Facsimile of the original edition of 1874. Edited by Gallo and Compañía. Mexico: Editorial Cosmos, 1975.

Cardoso, G. Negro slavery in the sugar plantations of Veracruz and Pernambuco, 1550-1680: a comparative study. University Press of America, 1983.

Carlson, R. E. The Liverpool \& Manchester Railway Project, 1821-1831. David \& Charles, 1969.

Castrejón Diez, J. Una ciudad minera en sus orígenes [A mining city in its origins.] Artes de México, 1989.

Castro, L. The Republic of Mexico in 1882 with Revised and Corrected Map. New York: Thompson \& Moreau Printers, 1882.

D’Estrabau, G. Historia de las Comunicaciones y Transportes en México. El Ferrocarril [History of Communications and Transports in Mexico. The Railway.] Mexico: Secretaría de Comunicaciones y Transportes, 1988.

David, N. and C. Kramer. Ethnoarchaeology in action. Cambridge: Cambridge University Press, 2001.

Diario Oficial de la Federación 06/05/1972. Ley Federal sobre Monumentos y Zonas Arqueológicos, Artísticos e Históricos [Federal Law on Archaeological, Artistic and Historic Monuments and Areas.]

Gallo, R. Mexican modernity: The avant-garde and the technological revolution. Cambdridge: MIT Press, 2005.

Garma Franco, F. Railroads in Mexico: an illustrated history. Vol. 1. Denver: Sundance Publications, c1985-c1988.

Haber, S. Industria y Subdesarrollo [Industry and Underdevelopment.] Mexico: Alianza Editorial, 1992.

Hardesty, D. L. and B. J. Little. Assessing site significance: A guide for archaeologists and historians. Rowman Altamira, 2009.

Hobsbawm, E. En torno a los orígenes de la Revolución Industrial [About the origins of the Industral Revolution.] 26 ed. Mexico: Siglo Veintiuno Editores, 1988.

Hudson, K. Industrial Archaeology. London: University Paperbacks, 1965.

Leatherman, T. "Health implications of changing agrarian economies in the Southern Andes." Human Organization 53 (1994): 371-380.

Litvak, J., and S. López Varela. "El patrimonio arqueológico en México" [Archaeological heritage in Mexico.] In El Patrimonio Nacional de México II. Coordinated by E. Florescano. Mexico: Biblioteca Mexicana, Consejo Nacional para la Cultura y las Artes, Fondo de Cultura Económica, 1997.

Map of the Interoceanic Railway of Mexico. The University of Arizona Library. Special Collection. G4411.P3 1890z, M3. c1890.

Martin, C. E. Rural society in colonial Morelos. University of New Mexico Press, 1985. 
Neaverson, P., and M. Palmer. Industrial archaeology: principles and practice. Routledge, 2012.

Ortigosa, J. L. C. "Mineras en el Guanajuato colonia" [Mining companies in colonial Guanajuato.] Temas americanistas 18 (2005): 4-39.

Ortiz Hernán, S. Los ferrocarriles de México. Una visión social y económica [Mexican railways. A social and economic vision.] First edition in two volumes. Vol. I: La luz de la locomotora. Mexico: Ferrocarriles Nacionales de México, 1987.

Oviedo Gámez, B. and I. Hernández Ibar. Reporte Nacional México 2012-2015. Report prepared for TICCIH Mexico, 2016.

Powell, F. W. The railroads of Mexico. Stratford, 1921.

Riguzzi, P. Ferrocarriles y vida económica en México, 1850-1950: del surgimiento tardío al decaimiento precoz [Railways and economic life in Mexico, 1850-1950: from late emergence to early decay.] Toluca: El Colegio Mexiquense, 1996.

Schivelbusch, W. The railway journey: The industrialization of time and space in the nineteenth century. University of California Press, 2014.

Stratton, M. and B. Trinder, Twentieth Century Industrial Archaeology. London: Spon Press, 2000.

The International Committee for the Conservation of the Industrial Heritage (TICCIH) and International Council on Monuments and Sites (ICOMOS). "Principles for the conservation of industrial heritage sites, structures, areas and landscapes (The Dublin Principles)." In The $17^{\text {th }}$ ICOMOS General Assembly. Paris, November 28, 2011.

The International Committee for the Conservation of the Industrial Heritage $(T I C C I H)$ and United Nations Educational, Scientific and Cultural Organization (UNESCO). "The Nizhny Tagil Charter for the industrial heritage." In The 2003 TICCIH Congress in Russia, Nizhny Tagil, 2003.

United Nations Educational, Scientific and Cultural Organization (UNESCO). "Recommendation concerning the safeguarding and contemporary role of historic areas." In The General Conference of the United Nations Educational, Scientific and Cultural Organization, nineteenth session. Nairobi, October 26 - November 30, 1976.

Womack, J. Zapata y la Revolución Mexicana [Zapata and the Mexican Revolution.] 26 ed. Mexico: Siglo Veintiuno Editores, 2004. 